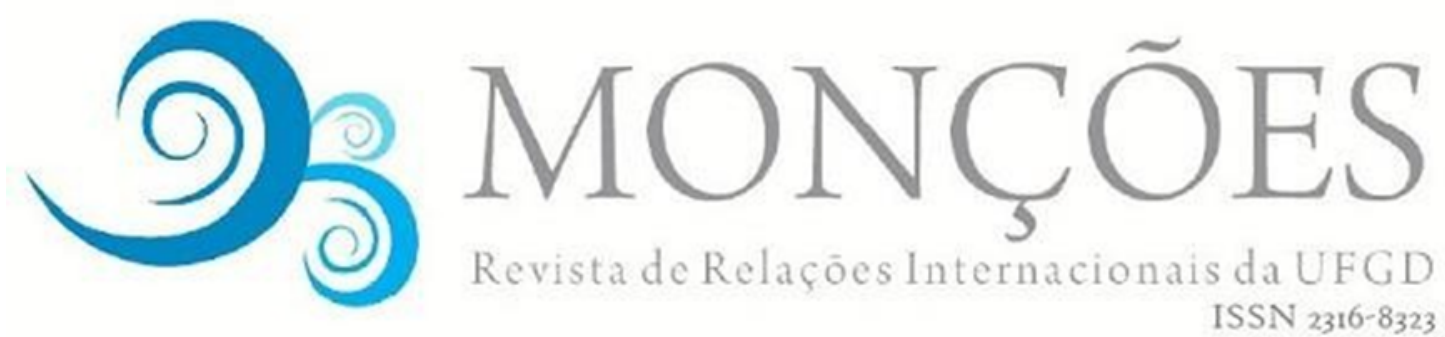

\title{
O TEMA DAS DROGAS NA AGENDA INTERNACIONAL DO BRASIL: A DEFINIÇÃO DE UMA NOVA AMEAÇA À SEGURANÇA NACIONAL NA DÉCADA DE 1990
}

\author{
PRISCILA VILLELA \\ Pontifícia Universidade Católica de São Paulo (PUC-SP), São Paulo, SP, \\ Brasil. \\ ORCID: https://orcid.org/0000-0003-2432-8900 \\ villela.priscila@gmail.com
}

\begin{abstract}
Resumo: O tráfico de drogas vem ganhando destaque na agenda de segurança internacional desde a década de 1990. Neste período, o tema das drogas passou a ser tratado politicamente como uma ameaça ao sistema internacional, aos estados nacionais e aos indivíduos. A noção de "guerra às drogas" produzida nos Estados Unidos foi internacionalizada e incorporada pelo regime internacional de proibição da ONU, a partir a partir do qual se universalizou. Ela também pautou a presença dos EUA na América Latina, moldando as políticas de drogas desses países. A postura do Brasil com relação ao tema das drogas mudou significantemente nesse período, quando sua dimensão internacional passou a ganhar destaque na agenda política. Nessa esteira, uma série de aparatos legislativos e institucionais foram fortalecidos e instituídos com o objetivo de combater o tráfico de drogas, avaliado como uma ameaça à segurança internacional. O objetivo deste trabalho é compreender como o Brasil incorporou as ideias, diretrizes e políticas estabelecidas internacionalmente ao longo da década de 1990, identificando atores doméstico e internacionais, suas decisões e os mecanismos que permitiram a internalização de diretrizes estabelecidas internacionalmente em torno do problema das drogas.
\end{abstract}

Palavras-chave: Drogas; Brasil; Segurança Internacional.

\section{THE DRUGS MATTER IN BRAZIL'S INTERNATIONAL AGENDA: A NEW THREAT TO NATIONAL SECURITY IN THE 1990s}

Abstract: Drug trafficking has been gaining prominence in the international security agenda since the 1990s. In this period, illegal drugs came to be treated politically as a threat to the international system, to national states and individuals. The notion of "war on drugs" produced in the United States was internationalized and incorporated by the UN's international prohibition regime, from where it became universal. It also guided the United States' presence in Latin America, shaping these countries' drug policies. Brazil's stance on the topic of drugs changed significantly during this period, when its international dimension gained prominence on the political agenda. In this context, a series of legislative and institutional devices have been strengthened and instituted with the aim of combating drug trafficking, which is seen as a threat to international security. The objective of this work is to understand how Brazil 
incorporated the ideas, guidelines and policies established internationally throughout the 1990s, identifying domestic and international actors, their decisions and the mechanisms that allowed the internalization of guidelines established internationally around the drug problem.

Key Words: Drugs; Brazil; International Security.

\section{EL TEMA DE LAS DROGAS EM LA AGENDA INTERNACIONAL DE BRASIL: LA DENICIÓN DE UMA NUEVA AMENAZA A LA SEGURIDAD NACIONAL EM LA DÉCADA DE 1990}

Resumen: El narcotráfico viene ganando protagonismo en la agenda de seguridad internacional desde la década de 1990. En este período, el tema de las drogas pasó a ser tratado políticamente como una amenaza para el sistema internacional, para los estados nacionales y individuos. La noción de "guerra contra las drogas" producida en EEUU fue internacionalizada e incorporada por el régimen internacional de prohibición de las UN, desde donde se volvió universal. También guió la presencia de Estados Unidos en América Latina, dando forma a las políticas de drogas de estos países. La posición de Brasil sobre el tema de las drogas cambió significativamente durante este período, cuando su dimensión internacional empezó a ganar protagonismo en la agenda política. En este contexto, se han fortalecido e instituido una serie de dispositivos legislativos e institucionales con el objetivo de combatir el narcotráfico, que es visto como una amenaza para la seguridad internacional. El objetivo de este trabajo es comprender cómo Brasil incorporó las ideas, lineamientos y políticas establecidas internacionalmente a lo largo de la década de 1990, identificando actores nacionales e internacionales, sus decisiones y los mecanismos que permitieron la internalización de los lineamientos establecidos internacionalmente en torno al problema de las drogas.

Keywords: Drogas; Brasil; Seguridad internacional.

\section{INTRODUÇÃO}

Este artigo se propõe avaliar as dimensões internacionais da construção do problema das drogas no Brasil enquanto uma ameaça à segurança nacional durante a década de 1990. Isso significa interpretar que esse período foi marcado pelo recrudescimento do combate às drogas no Brasil e que as definições sobre o problema das drogas e as respostas políticas adotadas pelos governos naquele período tinham origens internacionais. O que permitiu que o Brasil, no dado período, incorporasse concepções e definições consolidas internacionalmente sobre o tema das drogas foi, segundo esta pesquisa, a identificação do crescimento do tráfico de drogas na América Latina, a crescente presença norte-americana no combate às drogas na região, a pressão da ONU para que o Brasil adequasse sua legislação às convenções internacionais e a disposição das autoridades brasileiras em se 
adequarem às diretrizes de segurança que vinham sendo consolidadas internacionalmente.

As drogas são necessariamente um tema internacional, não apenas porque seu fluxo comercial atravessa fronteiras nacionais, mas também porque se tornou um tema de crescente relevância na agenda das Relações Internacionais desde o início do século passado, quando o proibicionismo se consolidou internacionalmente por meio dos tratados internacionais, inaugurado pela "Convenção do Ópio de 1912". Desde então, é impossível avaliar as decisões brasileiras com relação ao tema das drogas sem levar em consideração a forma como o tema foi historicamente tratado nos fóruns multilaterais ou as pressões externas sobre o país que decorreram disso. Nesse sentido, a influência internacional sobre o desenho da política de drogas brasileiras não é uma novidade, mas identificamos na década de 1990 uma nova virada desse processo, quando o tema ganhou destaque na agenda internacional do Brasil em razão de sua definição como uma ameaça à segurança internacional.

Existem convenções internacionais que tratam do tema das drogas desde o início do século passado. No entanto, foi sob o sistema da ONU que o regime de proibição global das drogas foi consolidado e universalizado. A "Convenção Única sobre Entorpecentes" de 1961, a "Convenção sobre Psicotrópicos" de 1971 e a "Convenção contra o Tráfico llícito de Entorpecentes e Substâncias Psicotrópicas" de 1988 se constituem como as principais referências deste regime. Se as duas primeiras convenções centravam-se majoritariamente na proteção à saúde pública e no dano causado pelas drogas ao indivíduo, a Convenção de Viena de 1988, por outro lado, passou a dar ênfase ao tráfico das drogas e sua relação com o crime organizado transnacional, definindo-o como uma ameaça à segurança internacional (DEL OLMO, 1990, p. 104). Pela primeira vez a ONU associou diretamente as drogas às organizações criminosas transnacional e, a partir da década de 1990, quase todos os documentos da organização passaram a se referir ao tráfico de drogas como um problema da segurança internacional em razão de seu vínculo com o crime organizado transnacional.

Tal evolução do regime internacional de proibição das drogas foi ao mesmo tempo acompanhada e influenciada pela agenda de segurança nacional dos Estados Unidos, que passou a incorporar o tema das drogas como um componente-chave da 
presença norte-americana na América Latina desde o final da década de 1980. Nesse contexto, o tráfico de drogas passou a ser apresentado por autoridades políticas norteamericanas como uma ameaça à segurança internacional e não apenas como um problema de ordem criminal (ANDREAS; NADELMANN, 2006, p. 11). Os crescentes índices de violência e de consumo nos Estados Unidos e na América Latina, a relação entre o tráfico de drogas com outros tipos de crime, como lavagem de dinheiro e o terrorismo, e transgressão das fronteiras nacionais para o comércio das drogas passaram a ser compreendidos politicamente como ameaça à segurança dos Estados (WILLIAMS, 1994, p. 330). Tais transformações se desenvolveram sobretudo nos Estados Unidos, a partir de onde essas diretrizes foram internacionalizadas.

Como objeto de estudos das Relações Internacionais o tema também se tornou relevante na mesma época, em resposta às transformações na forma como o tema passou a ser endereçado politicamente desde as duas décadas anteriores. A temática das drogas passou a ser progressivamente definida nas convenções internacionais e nos documentos norte-americanos que expõem as estratégias de seu combate como uma ameaça à segurança internacional. A crescente importância do tema na agenda regional da América Latina e bilateral entre o Brasil e os Estados Unidos foi decorrente desse processo. Levando em consideração o papel de tais processos, este artigo se propõe a compreender a forma como a definição das drogas como ameaça à segurança internacional foi incorporada pelas autoridades e políticas brasileiras durante a década de 1990.

A definição das drogas como uma ameaça à segurança internacional gerou desafios à disciplina de Relações Internacionais. Tradicionalmente, a segurança nacional foi definida em termos de ameaças militares representadas por outros Estados nacionais, sempre à luz da possibilidade da ocorrência de uma guerra interestatal. Segundo Stephen Walt (1991, p. 212), o foco dos estudos de segurança também deve se restringir, portanto, ao "fenômeno da guerra" e "estudo da ameaça, do uso e controle da força militar". No entanto, a inserção de temas não tradicionais na agenda de segurança internacional dos países criou uma profunda lacuna entre a definição conceitual e teórica do que seria a segurança e como de fato os Estados agiam a partir de suas definições discursivas e políticas de ameaça à segurança (ANDREAS; PRICE, 2001, p. 31). Um conjunto de autores interpretou que a definição 
discursiva de um objeto como ameaça à segurança não se limita ao recurso retórico e simbólico, mas como um mecanismo que reestrutura a forma como o tema é tratado politicamente (BUZAN et al., 1998).

Atentos a esse processo, há uma vasta literatura que tem refletido sobre as dimensões internacionais da "guerra às drogas" e a forma como a temática passou a ser endereçada a partir de uma linguagem da segurança. Alguns autores avaliam o movimento retórico que ascendeu o problema do crime e das drogas a um status de ameaça à segurança internacional nos Estados Unidos (p.e. ANDREAS; PRICE, 2001; PEREIRA, 2015; RODRIGUES, 2012). Outros, atentos aos resultados desse processo, identificam um processo de militarização do combate às drogas, a partir das intervenções norte-americanas ou do emprego de militares latino-americanos na segurança pública, sob incentivo dos Estados Unidos (p.e.BAGLEY; SALMERÓN CASTRO, 1991; DAMMERT, 2013; TOKATLIAN, 2015). Embora a literatura que se debruce sobre internacionalização da "guerra às drogas" na América Latina seja bastante vasta, há, contudo, um grupo um pouco mais restrito de trabalhos que se dedica a compreender como esse processo desenvolveu-se no Brasil. A dimensão internacional da política de drogas no Brasil tem sido endereçada no campo da Criminologia (p.e. CARVALHO, 2013; BOITEUX, 2006) das Ciências Sociais e das Relações Internacionais (p.e. HERZ, 2006; CARVALHO, 2013; SILVA, 2013; RODRIGUES; LABATE, 2016).

A partir dos avanços já alcançados pela literatura, esta pesquisa se propõe identificar laços entre as políticas de combate às drogas no Brasil e as diretrizes estabelecidas internacionalmente, sobretudo pela ONU e pelos Estados Unidos. O objetivo é demonstrar que a década de 1990 foi um momento de virada de um processo que já se construía desde as duas décadas anteriores. Nesse período, consolidou-se no Brasil a avaliação de que o tráfico de drogas se constituía como uma ameaça à segurança internacional do país. Para sustentar essa hipótese, nos apoiamos em fontes documentais variadas, como a legislação nacional e programas governamentais, os acordos internacionais, relatórios governamentais e intergovernamentais, assim como pronunciamentos de autoridades políticas e entrevistas veiculadas pela imprensa. Avaliamos a forma como o problema das drogas 
foi redefinido e, a partir disso, como as respostas políticas passaram a se adequar a essa nova avaliação (EDWARDS; GILL, 2002).

O trabalho está organizado em quatro partes além desta introdução. Na primeira sessão, desenvolveremos como consolidou-se o regime internacional de proibição que serviu de parâmetro e modelo para o a formulação das políticas de drogas no Brasil, destacando a mudança de abordagem da organização a partir da década de 1990, quando a dimensão da segurança internacional ganha centralidade na maneira como o tema passa a ser abordado. Na segunda sessão, identificamos os Estados Unidos como um protagonista nesse processo, espelhando suas próprias políticas de drogas nesse regime internacional em desenvolvimento. Por meio das organizações internacionais e também via esforços bilaterais, seu papel foi fundamental na redefinição do problema das drogas no Brasil. Na terceira sessão, nos voltamos ao nosso objeto de estudos, compreendendo como tais transformações foram incorporadas pelas autoridades e transformaram as políticas de drogas no Brasil. Por fim, apontamos algumas conclusões e possibilidades de novas agendas de pesquisa sobre o tema.

\section{A CONSOLIDAÇÃO DE UMA AGENDA GLOBAL PARA AS DROGAS}

As primeiras convenções internacionais que tratam do tema das drogas datam do início do século passado. No entanto, sob o sistema das Nações Unidas que um regime internacional de proibição se universalizou, consolidando um consenso internacional em torno do proibicionismo (BEWLEY-TAYLOR; JELSMA, 2011). Esse regime tem como objetivo promover a cooperação entre os Estados e a harmonização de suas legislações e das medidas de repressão à produção, comércio e consumo ilegais das drogas. Andreas e Nadelmann (2006, p. 17) cunharam o termo "regime de proibição global" para descrever o processo de homogeneização dos sistemas de justiça criminal e a regularização das relações e justiça criminal transfronteiriças. As atividades transnacionais, como é o caso do tráfico de drogas, se tornam objetos de regimes de proibição global como resultado da inadequação de medidas domésticas e unilaterais em contê-las, por se tratarem de crimes que burlam e atravessam as fronteiras e jurisdições nacionais (ANDREAS; NADELMANN, 2006, p.18). 
A evolução desse regime internacional foi ao mesmo tempo acompanhada e influenciada pela agenda de segurança nacional dos Estados Unidos, que passou a incorporar o tema das drogas como uma das ameaças sobre as quais deveriam se debruçar. Conforme supracitado, é possível identificar uma clara mudança na compreensão e na ênfase que foram dados ao problema das drogas ao longo as últimas convenções hoje em vigor. Desde o final dos anos 1980, quase todos os documentos das Nações Unidas passaram a se referir ao tráfico de drogas como um problema da segurança internacional em razão de seu vínculo com o crime organizado transnacional.

Definir um fenômeno como ameaça à segurança significa deslocá-lo da esfera da política normal para um campo caracterizado como emergencial, justificando medidas extremas e, por vezes, extraordinária em razão da ameaça existencial por ele representada (BUZAN et al., 1998, p.23). Conforme exposto na Convenção de 1988, o tráfico de drogas "é uma atividade delitiva internacional cuja supressão exige urgente atenção e a mais alta prioridade" (ONU, 1988, p. 3). Esse trecho revela a urgência que vinha sendo atribuída ao problema das drogas, a partir de então definida como uma ameaça à segurança internacional.

$\mathrm{Na}$ esteira desse processo, em 1997 foi criado o Escritório das Nações Unidas para Drogas e Crime (UNODC), que consolidou a relação estabelecida pela ONU entre droga e crime, inserindo-a na chave na agenda de combate ao crime transnacional. Essa reforma institucional revela a chave pela qual o tema das drogas seria abordado, não como parte de um debate de saúde e desenvolvimento, mas como uma ameaça à segurança, juntamente com terrorismo, pirataria, tráfico de armas, lavagem de dinheiro, corrupção, crime ambiental e justiça criminal, temas outros também sob os cuidados desse novo órgãos.

Por iniciativa norte-americana (Resolução A/RES/52/92), em 1998 foi aberta a $20^{\text {a }}$ UNGASS sobre o Problema Mundial das Drogas, um marco importante na consolidação do problema das drogas como uma questão de segurança. $\mathrm{Na}$ Declaração Política resultante desta reunião, foi reconhecido que as drogas ilegais "são uma grave ameaça à saúde e bem-estar de toda a humanidade, à independência dos Estados, à democracia, à estabilidade das nações, à estrutura de todas as sociedades e à dignidade de milhões de pessoas e suas famílias" 
(ONU, 1998, p. 3). Nesse mesmo sentido, também reforçou a relação estabelecida pela Convenção de 1988 entre as drogas e o crime organizado transnacional, o tráfico de armas, o terrorismo e a violência (ONU, 1998, p. 4).

$\mathrm{Na}$ ocasião, o Brasil teve uma participação bastante expressiva, inclusive elegendo a reunião para anunciar reformas em sua política doméstica de combate às drogas. A identificação do Brasil como país de trânsito e produtor de precursores químicos a partir da década de 1980 nos relatórios internacionais e a maior ênfase ao tráfico e ao crime organizado trazida pela Convenção de 1988 fizeram do país um ator central na cadeia do mercado das drogas. Tal narrativa resignificou a postura internacional do Brasil com relação às drogas na década de 1990. Luiz Felipe Lampreia, ministro das relações exteriores do governo de Fernando Henrique Cardoso, durante a LIV Sessão Ordinária da Assembleia Geral das Nações Unidas de 1999, disse entender que as drogas representam mais que uma ameaça à vida e ao futuro dos jovens, mas "um dos maiores desafios às sociedades democráticas (...), grave ameaça à segurança de instituições nacionais e dos próprios cidadãos, que pagam com suas vidas o preço intolerável desse fenômeno do nosso tempo" (apud. CORRÊA, 2007, p. 658). A partir da década de 1990, quase todos os discursos de presidentes e ministros das relações exteriores brasileiros à Assembleia Geral da ONU passaram a endereçar o problema das drogas como uma ameaça à segurança internacional. O Brasil, disposto a se engajar na nova agenda global, alinhou seus discursos e práticas, enquadrando tal abordagem em suas próprias políticas públicas. Desde a "Convenção do Ópio" de 1912 o Brasil foi um ator ativo na formulação do regime internacional de proibição das drogas, influenciando e sendo influenciado por seu desenvolvimento, de maneira que as transformações que marcaram esse período também incidiram sobre a política brasileira.

\section{A "GUERRA ÀS DROGAS" E A REDEFINIÇÃO DA AGENDA DE SEGURANÇA INTERNACIONAL NORTE-AMERICANA}

A era moderna do controle internacional do crime foi motivada especialmente pela campanha contra o tráfico de drogas promovida pelos Estados Unidos entre as décadas de 1960 e 1970, que acabou sendo incorporada pelas convenções da 
ONU. Nenhum outro país dedicou tanto esforço financeiro e diplomático na internacionalização de suas normas criminais e na coleta de dados sobre crimes e jurisdições de outros países. De fato, é possível afirmar que o modelo de proibição global adotado pela ONU é um reflexo do sucesso norte-americano em internacionalizar suas concepções sobre o tema (ANDREAS; NADELMANN, 2006, p. 106; BEWLEY-TAYLOR; JELSMA, 2011, p. 8). Os Estados Unidos usaram as organizações internacionais para criar, universalizar e supervisionar o modelo proibicionista norte-americano, assim como para promover seus interesses (ANDREAS; NADELMANN, 2006, p. 173).

Em 1971, o presidente norte-americano Richard Nixon elevou o tema das drogas a um status de ameaça ao país. Durante uma conferência de imprensa, afirmou que o "abuso de drogas" havia se tornado o "inimigo público número um" dos Estados Unidos da América (THE WHITE HOUSE, 1971). Contra tal inimigo, afirmou, era necessário iniciar uma guerra. A partir de então, o termo "guerra às drogas" passou a ser empregado recorrentemente nos discursos oficiais da maioria dos presidentes norte-americanos. Ronald Reagan (1981-1989), ao declarar sua própria "guerra às drogas", avaliou que as drogas se configuravam como uma ameaça à segurança internacional dos Estados Unidos e de todo o hemisfério (THE WHITE HOUSE, 1986, p. 1).

A política antidrogas dos Estados Unidos pressupunha que a repressão à oferta das drogas ilícitas, que eram produziram em outros países, reduziria a incidência de consumo e a expansão do crime nos Estados Unidos. A noção predominante era a de que as drogas tinham origem externa, representavam uma ameaça ao país, e deveriam ser combatidas por meio da erradicação de sua fonte e, portanto, da produção e cultivo de suas matérias-primas (DEPARTMENT OF STATE, 1998). Como resposta, portanto, a "guerra às drogas" tomou proporções internacionais. A partir de então o tráfico de drogas passou a ser usado como justificativa às intervenções de diferentes ordens na região (VILLA, 2010, p. 5). Os Estados Unidos passaram a investir em operações de interdição, na cooperação policial com os países produtores e de trânsito de drogas, na construção de políticas públicas, instituições e legislação de repressão ao crime em outros países, e até em intervenções militares. Sua forma de internacionalização, portanto, 
variaram entre pressões diplomáticas, incentivos econômicos, intervenções militares, campanhas de propaganda ou outras modalidades de ação internacional.

Visando a influenciar o combate às drogas em território estrangeiro e suprimir o tráfico das mesmas para os Estados Unidos, foram desenvolvidos mecanismos de pressão e coerção para garantir que os outros países replicassem políticas em conformidade com suas diretrizes. Para isso foi criado o processo de "certificação" em 1986, um mecanismo de monitoramento e avaliação das políticas de combate às drogas em outros países, partindo de critérios estabelecidos pelos acordos de cooperação internacional assinados com os Estados Unidos, pelas diretrizes estadunidenses de "guerra às drogas" e pelas convenções internacionais. Os países descertificados, segundo a Lei de Assistência Externa de 1961, são sujeitos a cortes da maior parte da assistência estrangeira. Além disso, a lei exige que os Estados Unidos votem contra o financiamento de seis bancos multilaterais de desenvolvimento para esse país. Segundo consta nos relatórios, é avaliado se o país "cumpriu as metas e objetivos da Convenção das Nações Unidas contra o Tráfico llícito de Estupefacientes e Substâncias Psicotrópicas" e se o país "cooperou totalmente com os Estados Unidos ou tomou as medidas adequadas por si só para alcançar o pleno cumprimento das metas e objetivos estabelecidos pela Convenção das Nações Unidas sobre Drogas de 1988" (DEPARTMENT OF STATE, 2000, p. 1). Ainda que formalmente poucos Estados tenham sido não certificado, o relatório produzido e publicado anualmente é utilizado como um instrumento político de nomear e envergonhar os países mal avaliados, podendo servir de base para pressão política estadunidense. Para citar um exemplo, desde 2008 a Bolívia deixe de ser certificada em resposta à expulsão de agentes da DEA e à promoção do cultivo e consumo tradicional da folha de coca (DEPARTMENT OF STATE, 2020).

Esse é o caso do Brasil, que vem sendo classificado pelos Estados Unidos desde então. Por meio dos relatórios "International Narcotics Control Strategy Report (INCSR)", foram avaliadas anualmente as ações de combate às drogas e as políticas de drogas brasileiras, bem como a disposição das autoridades do país em cooperar com os Estados Unidos. Para viabilizar formalmente essa cooperação, em 1986 o Brasil e os Estados Unidos assinaram o "Acordo de Cooperação Mútua 
para a Redução da Demanda, Prevenção do Uso Indevido e Combate à Produção e ao Tráfico llícito de Drogas". O acordo foi renovado e atualizado em 1995, a partir de quando a cooperação entre os países para este fim se intensificou.

A mudança no tom das políticas contra as drogas ao final da Guerra Fria foi evidente como resultado da redefinição das prioridades no campo da segurança internacional no contexto da nova ordem internacional que se consolidava com o fim da Guerra Fria. A partir de então, o espaço que o comunismo ocupava como imperativo moral da política externa norte-americana foi ocupado pela preocupação pelo tráfico de drogas e outros crimes transacionais, que assumiram espaço de destaque na agenda de segurança nacional (VILLA, 2010). Os anos 1990 marcam este período de transição de uma agenda de segurança nacional pautada em ameaças estatais para uma definição mais ampla de ameaças que poderiam ter origens não estatais, como o tráfico de drogas (PEREIRA, 2011, p. 77). Pereira (2015) identifica nesse trajeto histórico um processo de securitização do crime transnacional, por meio do qual os Estados Unidos mobilizaram recursos próprios da segurança nacional para lidar com o tema da criminalidade.

Declarar uma guerra às drogas e defini-la como uma ameaça à segurança nacional também significou para os Estados Unidos que o combate à produção, consumo e principalmente ao tráfico deveria ser conduzido por meios extraordinários e emergenciais, neste caso, por meio do emprego de recursos militares, próprios do campo da segurança internacional. Uma vez que a ameaça representada pelas drogas, segundo documentos norte-americanos, tinha origem internacional, as Forças Armadas em cooperação com as polícias passaram a atuar no combate às drogas também em território internacional, na forma de assistência militar na destruição de instalações de produção de drogas; colaboração com forças armadas da nação anfitriã para evitar a exportação de drogas ilícitas; e assistência à outra nação para ajudar a desenvolver alternativas econômicas para a produção, exportação e distribuição de drogas (BAGLEY 1991; WALKER III, 1999).

As ameaças de natureza transnacionais, identificadas pelas autoridades norte-americanas, tornaram turvas a tradicional distinção entre atividades de defesa e de policiamento, e entre segurança interna e externa e, portanto, entre as 
funções das forças armadas e da polícia (BIGO, 2000, p. 175). O processo chamado de "militarização" das polícias e "policização" das forças armadas tem sido um dos resultados desse processo, já que os elementos da guerra e os elementos da criminalidade mesclaram-se como parte do alargamento da agenda de segurança norte-americana (ANDREAS; PRICE, 2001, p. 35). Desde a década de 1990, recursos militares desenvolvidos para a guerra veem sendo cada vez mais empregados contra o crime transnacional (ANDREAS; PRICE, 2001, p. 38-40).

$O$ emprego de militares na "guerra às drogas" tornou-se um modelo incentivado e reproduzido em outros países, sobretudo na América Latina. Ao longo da década de 1990 os Estados Unidos pressionaram o Brasil e os demais países da América Latina para que reconhecessem o tráfico de drogas como uma ameaça à segurança regional e nacional de seus respectivos países e que, em decorrência disso, empregassem suas Forças Armadas na chamada "guerra às drogas" (HERZ, 2006, p. 203). Em 1992, com a missão de apresentar novas diretrizes estratégicas para a América Latina, o Secretário de Defesa Dick Cheney visitou alguns países da região, inclusive o Brasil, recomendando que as Forças Armadas reorientassem seu papel e se dedicassem ao policiamento, sobretudo contra o tráfico de drogas (BANDEIRA, 2010, p. 65).

Segundo a literatura e as declarações de autoridades à época, as Forças Armadas do Brasil desconfiavam dos interesses norte-americanos em intervir militarmente na região das fronteiras amazônicas sob o pretexto de combater as drogas, como um pretexto de estabelecer sua presença na Amazônia, e duvidavam das intenções do governo norte-americano em rebaixar o papel das Forças Armadas da região à função de polícia, considerado um pretexto para que os Estados Unidos colocassem a defesa nacional do Brasil sob sua tutela (BANDEIRA, 2010; HERZ, 2006). Por estas razões, questões relativas à presença militar norte-americana na região andina foram, por vezes, compreendidas como uma possível ameaça à Amazônia brasileira, sobretudo para os militares (CERVO; BUENO, 1992, p. 503). Apesar dessa avaliação, é possível identificar uma crescente participação das Forças Armadas brasileiras no combate ao tráfico de drogas no país a partir da década de 1990, que desenvolveremos no próximo tópico. 
A securitização do tema das drogas e do crime transnacional pelos governos estadunidenses a partir da década de 1970 demandou que a repressão ao crime também se transnacionalizasse, estimulando a crescente conexão entre agências policiais e militares do mundo. Desde a década de 1990, a Drug Enforcement Administration (DEA), polícia federal antidrogas dos Estados Unidos, vem promovendo a cooperação com a Polícia Federal do Brasil, o que inclui transferência de recursos, treinamento, compartilhamento de evidências e inteligência e financiamento de políticas públicas (VILLELA, 2020).

\section{DIMENSÕES INTERNACIONAIS DA “GUERRA ÀS DROGAS” NO BRASIL}

No Brasil, o controle legislativo sobre determinadas substâncias data do final do século XIX junto ao processo de institucionalização do saber e da prática médico-científica, àquela época, único ente responsável pela autorização do consumo de drogas (RODRIGUES, 2004, p.128). Naquele período, os próprios médicos e pesquisadores da área da saúde pressionaram pelo controle penal das drogas no Brasil neste período (BOITEUX, 2011, p.1). Ativo nesse processo, o Brasil foi o primeiro país do mundo a criminalizar a maconha, em 1830. Na ocasião, a Câmara Municipal do Rio de Janeiro passou a penalizar a venda e consumo do que era chamado de "pito de pango", substância associada aos negros escravizados (SAAD, 2013). De acordo com Saad (2013, p.5),

assim como o candomblé e a capoeira, a maconha estava associada aos africanos e seus descendentes e seu uso, além de prejudicar a formação de uma República moralmente exemplar, poderia se disseminar entre as camadas ditas saudáveis - leia-se brancas - e arruinar de vez o projeto de uma nação civilizada.

Nesse sentido, o desenvolvimento do proibicionismo no Brasil foi considerado por Torcato (2016) como um modelo internacional.

Uma vez assinada e sancionada a "Convenção do Ópio" de 1912 pelo Brasil (Decreto $\left.\mathrm{n}^{\circ} 11.48 \mathrm{I} / 15\right)$, a política criminal brasileira para as drogas começou a ganhar robustez (BATISTA,1997, p.131). As categorias de "toxicomania" e "entorpecente" foram consagradas pela legislação nacional em 1921 (Lei nº. 
4.294/2; Decreto n $14.969 / 21$ ), quando passou a ser prevista a pena de prisão para aqueles que traficassem cocaína, ópio, morfina e seus derivados e, portanto, quando as drogas passaram a ser reconhecidas pela lei como um problema público (TORCATO, 2013, p. 121). Em 1924, ocorreu a II Conferência Internacional do Ópio, ocasião em que os representantes brasileiros defenderam a limitação da produção e comercialização das drogas às necessidades médicas e científicas e expuseram os avanços da legislação brasileira nesse sentido. Uma série de normas de regulação e proibição das drogas foram criadas no Brasil, a partir de então, sob a influência das convenções internacionais (BATISTA, 1997, p. 132).

O Brasil desempenhou um papel ativo na idealização e elaboração do proibicionismo internacionalmente, desde sempre alinhado à posição dos Estados Unidos e contrária àquela defendida pelos grandes impérios e produtores, como Índia, Bolívia ou Peru, preocupados com a comercialização de substâncias em vias de proscrição (TORCATO, 2016, p.150). À época, os Estados Unidos passaram a defender que os países produtores eram os verdadeiros responsáveis pelo consumo de drogas mundialmente (MUSTO, 1999, p. 197; TROCATO, 2016, p.146). Segundo Torcato (2016, p.150), o Brasil já "se colocava na condição de representante de uma política americana", uma vez que os Estados Unidos protagonizaram o movimento proibicionista internacional desde as primeiras convenções sobre o tema, no início do século.

A Comissão Nacional de Fiscalização de Entorpecentes (CNFE), uma organização que reunia diversas agências públicas e organizações da sociedade civil visando a condução das políticas de drogas brasileiras, instituída pelo DecretoLei no 891 em 1938, foi um esforço brasileiro de internalizar as orientações presentes nas convenções internacionais (CARVALHO, 2013). Domesticamente, essa iniciativa se reverteu em operações de repressão ao consumo de drogas, especialmente voltadas ao consumo da chamada "diamba" em regiões do nordeste brasileiro (CARVALHO, 2013, p. 88). As leis, políticas e instituições governamentais dedicadas ao tema das drogas foram desenvolvidas, ao longo do século vinte no Brasil, à luz das diretrizes negociadas internacionalmente e promovidas pelos Estados Unidos (SILVA, 2013). 
Na década de 1970, o tema das drogas voltou ao debate público no Brasil sob novos contornos, como resposta a estímulos internacionais. Nos Estados Unidos, crescia a preocupação com um identificado aumento da produção de cocaína na América Latina. Nesse sentido, o país passou a ganhar destaque e menção nos relatórios internacionais produzidos pela ONU e pelos Estados Unidos como importante rota da cocaína produzida no Peru, Bolívia e Colômbia para os Estados Unidos e Europa (DEPARTMENT OF STATE, 1996; ONU, 1983). Assim, a luz sobre o problema do consumo de drogas cada vez mais se voltou à dimensão internacional do tráfico de drogas, tema que passou a ser recorrentemente mencionado nos discursos de presidentes e chanceleres frente à ONU a partir de então. Desde o final da década de 1980, todos os discursos brasileiros na Assembleias Gerais abordaram o problema do tráfico internacional de drogas associando-o a um problema da segurança do país e da região (CORRÊA, 2007), o que demonstra um uma disposição das autoridades políticas do país em endereçar o tema internacionalmente.

Dentro desse quadro a primeira lei autônoma e unicamente dedicada a estabelecer os termos da proibição às drogas foi criada. A Lei 6.368/76 instaurou no Brasil um modelo inédito de controle ao consumo e ao tráfico de drogas, acompanhando as orientações político-criminais dos países centrais, sobretudo dos Estados Unidos, refletidas nos tratados e convenções internacionais das Nações Unidas (CARVALHO, 2013, p. 57). A recomendação da Convenção Única de 1961 (Art. 36) de que "as infrações graves sejam castigadas de forma adequada, especialmente com pena prisão ou outras de privação da liberdade" foi adotada pelo Brasil, segundo Boiteux (2006, p. 149), que estabeleceu a prisão como pena principal aos delitos associados às drogas, inclusive para o usuário. Tal lei previa pena de três a quinze anos de prisão para o traficante e pena de seis meses a dois anos de prisão para o usuário ${ }^{1}$. A chamada "Lei dos Tóxicos" de 1976 manteve-se

\footnotetext{
${ }^{1}$ Os verbos que descrevem os delitos sob pena de três a quinze anos de prisão incluem também "trazer consigo" e "guardar", coincidindo com os verbos que definem a pena para usuário: "adquirir, guardar ou trazer consigo", diferenciados apenas pela identificação do "para uso próprio", dando espaço para arbitrariedades do aplicador da lei.
} 
em vigor até $2006^{2}$, enquanto as políticas voltadas às drogas foram se tornando cada vez mais repressivas. A "Nova Lei de Drogas" de 2006 eliminou a pena de prisão para usuários, ainda que sem descriminalizar o consumo, mas ao mesmo tempo reforçou a tendência em curso de endurecer as penas contra o tráfico (CAMPOS, 2015). Uma vez que a lei não ofereceu possibilidade de distinção entre usuários e traficantes, o resultado foi o encarceramento em massa da população negra e de periferia, sujeita à seletividade e arbitrariedade do sistema policial e penal (CAMPOS; ALVAREZ, 2019).

Nesse período, crescia também a preocupação com relação à posição do Brasil como país de trânsito em resposta às menções ao país que vinham sendo destacadas com cada vez mais frequências nos relatórios sobre tráfico e consumo de drogas produzidos pela ONU e pelos Estados Unidos. "Brasil, rota importante para o tráfico de drogas", segundo declaração de John R. Thomas, secretário adjunto de Estado dos Estados Unidos (O ESTADO DE S. PAULO, 1982, p. 25); "ONU, a nova aliada do Brasil contra as drogas" (O ESTADO DE S. PAULO, 1985, p. 12). "ONU adverte: Brasil ameaçado pelos tóxicos" (O ESTADO DE S. PAULO, 1987, p. 11), foram manchetes veiculadas na grande imprensa nesse período. $\mathrm{Na}$ avaliação de Adorno e Salla (2007, p. 14), nem sempre os crimes conectados com consumo e o tráfico de drogas se configuraram como objeto de inquietação coletiva ou matéria privilegiada das políticas públicas dos órgãos encarregados da repressão ao crime. Foi apenas a partir do momento em que o crescente consumo de drogas passou a ser documentado em relatórios internacionais e a inserção de cidadãos procedentes dos estratos socioeconômico de baixa renda no comércio ilegal de drogas passou a ser notada pelas autoridades (ADORNO, SALLA, 2007, p. 14), que o tema das drogas tomou um lugar de destaque na agenda política e de segurança doméstica e, posteriormente, internacional do país. Assim, um processo que já vinha em curso desde a década de 1970 se consolidou nos anos 1990,

\footnotetext{
${ }^{2}$ Em meio a esse período de 30 anos, foi aprovada em 2002 uma nova lei das drogas (Lei $n^{\circ}$ 10.409/02) que acabou coexistindo com a lei de 1976. O projeto original (Projeto de Lei $n^{\circ}$ 105/1996, de autoria de Ricardo Sérgio) propunha a despenalização do uso e o porte de entorpecentes para uso próprio, mas a grande oposição a estes termos fez com que a lei fosse aprovada com trinta e cinco vetos da presidência da república, que atingiram cerca de $83 \%$ do texto (BOITEUX, 2006, p. 178). Isso resultou na aprovação de uma lei retalhada que entrou em vigor juntamente com a lei anterior (Lei $n^{\circ} 6.368 / 76$ ), que não foi revogada.
} 
quando a dimensão internacional do problema das drogas ganha destaque e quando o tema passa a compor a agenda de segurança e de política internacional do Brasil.

Em meados da década de 1980 o Brasil passou por um processo de transição política que restabelecia o regime democrático no país, depois de duas décadas de ditadura militar. Na ocasião da Assembleia Nacional Constituinte de 1987 e da promulgação da Constituição da República de 1988, uma série de avanços, em termos de garantias de direitos individuais e de direitos humanos, foram consolidadas, mas é marcante o recrudescimento da política criminal como um todo, com a inclusão no texto constitucional do conceito de crime hediondo, por exemplo, o que repercutiu diretamente sobre as políticas de combate às drogas (CARVALHO, 2013, p. 90-91; BOITEUX, 2011, p. 32).

Reforçando a disposição das autoridades brasileiras em endereçar a temática, em 1991 foi aberta uma Comissão Parlamentar de Inquérito (CPI) destinada a investigar a impunidade ao tráfico de drogas no país, assim como o crescimento do consumo (RCP 3/1991). O relatório final concluiu que "cresce o poder do narcotráfico. Esse poder ameaça, alicia, mata. Onde consegue chegar ao governo, destrói a democracia" (CÂMARA DOS DEPUTADOS, 1991). Enquanto isso, na Câmara dos Deputados, circulava o Projeto de Lei $n^{\circ} 1.873 / 91$, de autoria de Elias Murad (PSDB-MG), que propunha o endurecimento da lei antidrogas, recomendando o aumento da pena do tráfico para seis a quinze anos de prisão.

Neste mesmo ano, foi aprovada a expropriação de terras onde fossem encontradas culturas ilegais de drogas (Lei n 8.257/91). Segundo esta lei, as terras com culturas ilegais de drogas seriam imediatamente expropriadas e destinadas ao cultivo de produtos alimentícios e medicamentosos, sem qualquer indenização ao proprietário (Art. 1). Os valores apreendidos em decorrência do tráfico poderiam ser revertidos em benefício de atividades de fiscalização, controle, prevenção e repressão do crime de tráfico dessas substâncias por meio do FUNCAB.

Em 1993 foi criada Secretaria Nacional de Entorpecentes (Lei n 8.764/93), que passou a acompanhar a execução das normas estabelecidas pelo Conselho Federal de Entorpecentes (COFEN), criado em 1980. Em reação, o International Narcotics Control Board (INCB) da ONU denunciou o Brasil por não colocar seus 
termos em prática, sobretudo aqueles referentes à supressão da produção de precursores químicos. Apesar disso, reconhecia que em razão da instabilidade política gerada pelo impeachment do presidente Collor, o Brasil não havia tido condições de dar prioridade às políticas contra as drogas durante o governo Itamar Franco (ONU, 1994, p. 43).

Com a eleição do Presidente Fernando Henrique Cardoso (1994-2002), a INCB lançou publicamente exigências de que o Brasil desenvolvesse, adotasse e implementasse políticas adequadas com relação às drogas, conforme previsto da Convenção de Viena de 1988 (ONU, 1995). O tratado havia sido assinado pelo Brasil no mesmo ano, mas ratificado e promulgado pelo Congresso Nacional em 1991 (Decreto $n^{\circ}$ 154/91). Do texto do documento, os crimes associados às drogas passaram a ser diretamente vinculados ao crime organizado, que deveria ser combatido por meio da cooperação internacional, da criminalização da lavagem de dinheiro, confisco dos ativos financeiros e da criação de instrumentos investigatórios mais sofisticados. Por esta razão, uma missão da INCB e da UNODC foi enviada em 1995 ao Brasil para dar assistência e pressionar as autoridades no desenvolvimento de uma nova legislação para as drogas voltada a tais preocupações (ONU, 1995, p. 61).

A Convenção de 1988 estabeleceu como um de seus objetivos o monitoramento e o controle de substâncias químicas usadas no preparo e manufatura de drogas ilícitas. O Brasil era recorrentemente mencionado nos relatórios da INCB pelo pouco controle sobre químicos utilizados à produção de cocaína (ONU, 1983, p. 29). Se adequando a tais diretrizes, em 1995 foi aprovada Lei 9.017/95 que estabeleceu o controle sobre precursores químicos destinados à produção de cocaína e outras drogas. Igualmente em razão da importância trazida pela Convenção de 1988 à associação entre drogas e crime organizado, em 1995 pela primeira vez houve a tipificação de quadrilha ou bando criminosos pela lei brasileira (lei $n^{\circ}$ 9.034/95), impondo-Ihes penas específicas. Contudo, sem estabelecer uma definição jurídica ao conceito de crime organizado, que só viria a acontecer por meio da Lei no 12.850 de 2013.

Em 1996 foi lançado o Programa de Ação Nacional Antidrogas (PANAD). Montado na Secretaria de Planejamento de Ações Nacionais de Segurança 
Pública, do Ministério da Justiça, a pedido do presidente Fernando Henrique. O programa previa um investimento de US\$250 milhões nos próximos quatro anos (FOLHA DE S. PAULO, 19 de abril de 1996). Segundo o Ministro da Justiça Nelson Jobim, o PANAD "resume de forma clara a vontade do Estado brasileiro de enfrentar o problema de frente, sem demagogia ou sensacionalismo" (JOBIM, 22 de novembro de 1996). Anteriormente ao seu lançamento, Nelson Jobim viajou para Washington para conhecer o modelo de política antidrogas norte-americano e apresentar às autoridades especialistas norte-americanas o projeto brasileiro de combate à lavagem de dinheiro. De acordo com o embaixador do Brasil na OEA, Sebastião do Rego Barros, o PANAD se desenvolveu "à luz dos dispositivos da Convenção de Viena, de 1988" (MRE, 1996). Além disso, segundo Nelson Jobim, representou uma resposta do Estado brasileiro ao compromisso assumido no âmbito da Estratégia Antidrogas no Hemisfério da OEA de 1996.

A compreensão de que o tráfico de drogas alcançava proporções cada vez mais alarmantes e gerava dados sociais cada vez mais graves pressionou as autoridades políticas para que se posicionassem sobre o tema e tomassem medidas emergenciais para conter o que já se entendia como uma ameaça à segurança nacional e internacional do país. Esta preocupação se manifestou e se formalizou na publicação da Política de Defesa Nacional (PDN) de 1996. Lançada pelo recém-criado Ministério da Defesa, seu objetivo foi definir uma política de defesa nacional que delineasse as ações do governo a um objetivo único. O PDN propôs uma revisão das estratégias no Brasil na área da segurança nacional, dadas as transformações na ordem internacional. Segundo o documento, a defesa nacional do país deve trabalhar dentro de um contexto regional que inclui

Zonas de instabilidade que podem ter efeitos negativos sobre os interesses brasileiros. São motivo de preocupação as ações das bandas armadas que estão ativas nos países que fazem fronteira com a Amazônia brasileira e o delito internacional (PRESIDÊNCIA, 1996, p.10).

Em referências ao crime que atravessa as fronteiras do país, o documento registra a inclusão do tema das drogas em uma agenda de segurança nacional do país. 
Os relatórios produzidos pela INCB desde o início da década já mencionavam o Brasil como um ator chave no processo de lavagem de dinheiro do tráfico de drogas na América Latina (ONU, 1992, p. 44). Por conta disso, os sucessivos relatórios pressionavam os governos brasileiros para que fosse adotada uma legislação específica que prevenisse as atividades de lavagem de dinheiro. Segundo o relatório do INCB de 1995,

\begin{abstract}
A INCB insiste que Governo do Brasil a realize, o mais breve possível, o desenvolvimento, a adoção e a implementação de uma legislação adequada, porque a situação do país o torna atraente para as pessoas que se envolvem em lavagem de dinheiro (ONU, 1995, p. 45).
\end{abstract}

Em 1995, o Ministério da Justiça criou uma comissão comandada por Nelson Jobim para elaborar o projeto de lei de combate à lavagem. Devido à demora na sua aprovação, em 1997 mais uma vez as Nações Unidas exigiram, por meio do relatório do INCB, que o Brasil agisse com urgência na aprovação de uma lei que criminalizasse a lavagem de dinheiro e pediu urgência ao governo brasileiro (ONU, 1997, p. 46). Enquanto isso, os Estados Unidos promoviam uma série de eventos e treinamentos voltados à investigação e combate à lavagem de dinheiro a policiais e juízes federais brasileiros (DEPARTMENT OF STATE, 1997). Policiais, procuradores e outras autoridades do Brasil visitaram os Estados Unidos para observar o modelo empregado em forças-tarefa de combate ao crime e compartilhar análise militares e de defesa com o objetivo de proporcionar uma visão regional para a ameaça representada pelo tráfico internacional de drogas (DEPARTMENT OF STATE, 1997).

Finalmente, no dia 3 de março de 1998 foi criminalizada a lavagem de dinheiro no Brasil (Lei 9.613/98) como resultado de uma pressão direta da ONU e dos Estados Unidos sobre autoridades do país. Foram definidas pela lei como atividades antecedentes à lavagem de dinheiro, o tráfico de drogas, terrorismo, contrabando de armas, extorsão mediante sequestro, corrupção, infração contra o sistema financeiro nacional e atividades praticadas pelo crime organizado. Esta lei também criou o Conselho de Controle de Atividades Financeiras (COAF), subordinado ao Ministério da Fazenda, com a finalidade de disciplinar, aplicar 
penas administrativas, receber, examinar e identificar as ocorrências suspeitas de atividades financeiras ilícitas. Concomitantemente foi criado no Banco Central do Brasil o Departamento de Combate a llícitos Cambiais e Financeiros.

Considerada a gravidade do crime e a necessidade de trata-lo por meios excepcionais, em 1998 também foi aprovada a possibilidade de quebra do sigilo bancário, que exigiu uma emenda à Constituição Federal de 1988. Segundo Machado (2007, p. 19), o Brasil adotou o mesmo modelo norte-americano, baseado no Bank Secrecy Act de 1970, que impõe aos bancos a obrigatoriedade de manter registros das operações bancárias durante cinco anos e de preencherem um formulário para informar ao Banco Central os casos de transações correntes que excedam o valor de US $\$ 10.000,00$ (mesmo valor adotado pelo Brasil) e pareçam ser suspeitas ou atípicas. Em reconhecimento a tais esforços, em 2000, o Brasil foi convidado a se tornar membro do Financial Action Task Force (FATF), órgão pertencente à Organização para a Cooperação e Desenvolvimento Econômico $(\mathrm{OECD})$, como um sinal de reconhecimento de que o país teria se adequado às normas internacionais de controle das atividades financeiras e de controle à lavagem de dinheiro (FATF, 2000, p.10). Apesar de reconhecer que o sistema era ainda muito recente, o relatório da FAFT de 2000 pressionou o Brasil para que apresentasse algum resultado, até então nulo, em termos de processos e condenações por lavagem de dinheiro nos anos seguintes (FAFT, 2000, p. 11).

$\mathrm{Na}$ mesma direção, em 1998 foi lançado o Sistema Nacional Antidrogas (SISNAD) estabelecido por meio do Decreto 2.632 em 19 de junho de 1998. O SISNAD mantinha em vigor a "Lei dos Tóxicos", mas se propunha a criar um sistema competente para formular a política nacional antidrogas em prevenção e repressão, integrar os planos nacionais com os estaduais e municipais e estabelecer o diálogo e troca de informações entre as diferentes instâncias competentes no combate às drogas, nos níveis federal, estadual, municipal e também internacional (Decreto 2.632/1998). Passaram a fazer parte do SISNAD o Conselho Nacional Antidrogas (CONAD), a Casa Militar da Presidência da República, o Ministério da Saúde, o Conselho Nacional de Educação, a Secretaria da Receita Federal do Ministério da Fazenda, o Departamento de Polícia Federal do Ministério da Justiça e o Ministério da Previdência e Assistência Social. 
O CONAD substituiu o antigo COFEN e assumiu o poder normativo sobre os demais órgãos integrantes do SISNAD no que compete às atividades disciplinadas pelo sistema (Decreto 2.632/1998). O conselho, de ordem normativa, deixou de ser comandado pelo Ministro da Justiça e passou a ser presidido pelo Chefe da Casa Militar, como indicativo da prioridade que o tema assumiu na agenda política. $O$ órgão foi composto pelo Secretário Nacional Antidrogas (SENAD); por um representante do Estado Maior das Forças Armadas; um jurista de comprovada experiência no assunto, indicado pelo Ministro de Estado da Justiça; um médico psiquiatra de comprovada experiência, indicado pela Associação Médica Brasileira; por representantes do Ministério da Saúde; um integrante do Ministério da Educação e Desporto; um do Ministério da Previdência e Assistência Social; um do Ministério Relações Exteriores; e dois do Ministério da Justiça, sendo um obrigatoriamente do órgão de repressão a entorpecentes. O SISNAD instituiu ao CONAD o poder de aprovar a Política Nacional Antidrogas (PNAD), exercer orientação normativa de prevenção e repressão às drogas, aprovar a destinação dos recursos do FUNCAB, gerir e acompanhar as atividades financiadas pelo FUNCAB e o desempenho da Política Nacional Antidrogas, bem como integrar ao Sistema os órgãos congêneres dos estados, do Distrito Federal e dos municípios.

Como órgão executivo do sistema, foi criada a Secretaria Nacional Antidrogas (SENAD), que substituiu a antiga Secretaria Nacional de Entorpecentes (1993). As prerrogativas da SENAD eram inicialmente bastante amplas, com a função de integrar toda a política governamental de prevenção e repressão do tráfico de ilícitos e abuso de drogas, incluindo a definição de políticas para o tratamento de usuários. Além disso, era também sua responsabilidade administrar a realização de acordos internacionais bilaterais sobre o tema do tráfico internacional (Decreto 2.632/1998). O objetivo do governo foi criar uma agência de mobilização nacional contra as drogas, inspirada na DEA norte-americana, capaz de centralizar as ações de repressão e prevenção do governo. 
Em razão disso, a criação da SENAD gerou disputas entre a Casa Militar/ Gabinete de Segurança Institucional ${ }^{3}$ e o Ministério da Justiça sobre o comando da repressão ao tráfico de drogas. Isso porque a antiga política de prevenção e repressão às drogas, coordenada pela Secretaria Nacional de Entorpecentes (COFEN) era comandada pelo Ministério da Justiça até que fosse criada a SENAD, a partir de quando a Casa Militar (Gabinete de Segurança Institucional) passou a comandar estas políticas, disputando ou sobrepondo-se sobre a autoridade do Ministério da Justiça e do Departamento da Polícia Federal (DPF) no comando sobre a repressão ao tráfico. Segundo a Constituição de 1988 (Art. 144), é função da Polícia Federal "prevenir e reprimir o tráfico ilícito de entorpecentes e drogas afins, o contrabando e o descaminho, sem prejuízo da ação fazendária e de outros órgãos públicos nas respectivas áreas de competência" (§ $\left.1^{\circ} \mathrm{II}\right)$.

Para resolver tal conflito, Fernando Henrique Cardoso propôs a revisão da SENAD. Por meio do Decreto 3.696/2000, determinou que a secretaria ficaria encarregada da política de prevenção e tratamento de dependentes, enquanto a Polícia Federal, sob o Ministério da Justiça, ficaria encarregada da repressão às drogas. Sobrou ainda à SENAD a função de decidir sobre o destino dos bens apreendidos (com exceção das armas de fogo) depois de encaminhados os processos ao Ministério Público Federal (Lei 10.409/2002), mas foi transferida ao Ministério da Justiça a responsabilidade sobre os acordos internacionais em matéria de cooperação policial no combate ao crime. Se não foi possível a criação de uma "DEA brasileira", os esforços de cooperação norte-americanas mantiveramse voltadas à Polícia Federal e aos departamentos dedicados ao tema.

A criação da SENAD foi comemorada pelo governo dos Estados Unidos, que no "International Narcotics Control Strategy Report (INCSR)" de 1998, declarou que:

o Brasil tem feito progressos substanciais no aumento da sua postura antidrogas em 1998. O presidente Fernando Henrique Cardoso declarou drogas ilícitas uma questão de interesse nacional e criou uma nova Secretaria Nacional Antidrogas (SENAD) para

${ }^{3}$ A Casa Militar da Presidência da República (Lei 8. 490/92) foi transformada em Gabinete de Segurança Institucional por meio da Lei $n^{\circ}$ 9. 649/98. 
coordenar todos os programas antinarcóticos e esforços (DEPARTMENT OF STATE, 1998).

Não por um acaso, a $20^{a}$ Sessão Especial da Assembleia Geral da Organização das Nações Unidas (UNGASS, sigla em inglês) foi escolhida para o presidente Fernando Henrique Cardoso anunciar a criação deste novo sistema nacional de combate às drogas. Em seu discurso, o presidente declarou que:

O Brasil não cruzará os braços diante das drogas, um inimigo insidioso, que ameaça o equilíbrio das famílias, a vida dos jovens e o tecido básico da sociedade (...) A guerra contra as drogas só será vencida se for conduzida em várias frentes simultaneamente. Nela, o êxito será medido, acima de tudo, pela capacidade de assegurar um futuro sem drogas à juventude de nossos países (...) Estou aqui para assegurar-lhes que o Brasil continuará a honrar sua parcela de responsabilidade nesse esforço (...) Estamos enviando uma mensagem clara a nossos jovens: a de que uma vida com drogas é escravidão, autodestruição e morte (...) Estamos enviando uma mensagem igualmente clara aos que lucram com a ignomínia desse comércio: a de que não encontrarão no Brasil qualquer tolerância com suas atividade (CARDOSO, 1998, p. 526).

As transformações na política de drogas brasileiras respondiam não apenas a demandas locais, mas também a uma audiência internacional, que influenciava e pressionava autoridades brasileiras nesse sentido.

Em seguida à reunião, o vice-presidente Marcos Maciel declarou reconhecer que as drogas eram um problema internacional e que o tráfico havia se internacionalizado "antes mesmo da globalização" (RODRIGUES, 9 de junho de 1998). Por entender que o problema já havia atingido um nível de epidemia no país, ele garantiu que o governo iria "promover uma guerra contra o narcotráfico" (RODRIGUES, 9 de junho de 1998), reproduzindo o recurso retórico norteamericano. Walter Maierovitch, então chefe do SENAD (1998-2000), respondendo sobre a importância da participação do Brasil na $20^{\circ}$ UNGASS, afirmou que é

a partir do momento que as organizações do tráfico fizeram do Brasil um mercado e um corredor de passagem das drogas, essa se tornou uma questão de preservação do Estado democrático de direito e de defesa dos direitos e garantias individuais (EVELIN; FARIA, 23 de junho de 1999). 
Na primeira reunião do SISNAD foi lida uma carta da ONU, pedindo ao país a criação de uma força tarefa contra as drogas (BRAGA; MONTEIRO, 1 de abril de 1999). Para Fernando Henrique Cardoso, o problema das drogas havia atingido proporções tais que "o mundo inteiro se angustia", "arruína a saúde e a própria vida" e que ameaça "segurança dos estados e a soberania das nações" (PRESIDÊNCIA, 2002, p. 1), dando um tom de emergência e ameaça representada pelas drogas. $A$ criação do SENAD, segundo o Presidente, respondia, portanto, à necessidade de

colocar o combate às drogas no alto das prioridades do Governo Brasileiro. Por isso, a Secretaria Nacional Antidrogas ficou vinculada à Presidência da República, numa posição que tanto sinaliza essa prioridade como, do ponto de vista operacional, permite coordenar melhor as ações dos vários órgãos do governo (PRESIDÊNCIA, 2002, p. 1).

Concomitantemente à criação da SENAD, foi aberta uma Comissão Parlamentar de Inquérito (CPI) na Câmara dos Deputados, denominada CPI do Narcotráfico, realizada em 1999, para investigar a extensão do tráfico de drogas no país. O tema dominou as manchetes de jornais durante meses ao descrever uma complexa rede de tráfico internacional envolvendo corrupção, lavagem de dinheiro e a participação de agentes públicos, como agentes da justiça criminal, policiais e políticos.

Em 2002 foi lançava uma nova Polícia Nacional Antidrogas (PNAD) (Decreto $\left.n^{\mathrm{a}} 4.345 / 02\right)$. Na introdução do documento, que expõe os motivos e diretrizes gerais sob as quais as medidas de combate às drogas deveriam se pautar, é referido o encontro da UNGASS de 1998 reforçando a concepção lá acordada de que:

O uso indevido de drogas constitui, na atualidade, séria e persistente ameaça à humanidade e à estabilidade das estruturas e valores políticos, econômicos, sociais e culturais de todos os Estados e sociedades (...) Suas consequências infligem considerável prejuízo às nações do mundo inteiro, e não são detidas por fronteiras: avançam por todos os cantos da sociedade e por todos os espaços geográficos, afetando homens e mulheres de diferentes grupos étnicos, independentemente de classe social e econômica ou mesmo de idade (PRESIDÊNCIA, 2002, p. 5). 
O uso de drogas é definido como uma ameaça à humanidade, à estabilidade das economias, das sociedades e dos Estados, o que acarreta a responsabilização dos usuários pelos males associados às drogas. $\mathrm{O}$ tráfico de drogas, ainda assim, não deixa de ser mencionado como um aspecto relevante do problema das drogas. Assim como o usuário, o tráfico de drogas também foi considerado pelo documento uma

\begin{abstract}
questão de relevância, na discussão dos efeitos adversos gerados pelo uso indevido da droga, é a associação do tráfico de drogas ilícitas e dos crimes conexos, geralmente de caráter transnacional, com a criminalidade e a violência. Esses fatores ameaçam a soberania do País e afetam a estrutura social e econômica interna, exigindo que o Governo adote uma postura firme de combate a tais ilícitos, articulando-se internamente e com a sociedade, de forma a aperfeiçoar e otimizar seus mecanismos de prevenção e repressão e garantir o envolvimento e a aprovação dos cidadãos (PRESIDÊNCIA, 2002, p. 5).
\end{abstract}

Nesta passagem o tráfico de drogas é definido como um ameaça à soberania do país e, portanto, é formalizada, por meio da PNAD, sua definição como ameaça à segurança nacional brasileira. $\mathrm{O}$ documento reproduz uma visão extremamente alarmante e emocional do problema das drogas, seguindo as tendências presentes nos documentos da ONU e dos Estados Unidos. Em uma carta introdutória ao documento, Fernando Henrique Cardoso anuncia que "vamos nos dar as mãos para defender a saúde e a vida dos nossos jovens e afastar a sombra que a indústria criminosa da droga lança sobre o futuro do nosso país" (PRESIDÊNCIA, 2002, p. 3). Diante do II Fórum Nacional Antidrogas, Fernando Henrique Cardoso declarou que "a Política Nacional Antidrogas que estamos apresentando oficialmente à Nação já é o resultado de uma mudança de atitude" (MRE, 2001, p. 220).

Tal revisão legislativa e institucional empreendida pelo Brasil confirmou, na avaliação de autoridades dos Estados Unidos, o "compromisso brasileiro e forneceu instrumentos importantes para os esforços antidrogas", na avaliação dos Estados Unidos (DEPARTMENT OF STATE, 1998). Muitas das leis que hoje regulam o combate ao crime transnacional no Brasil só puderam ser aprovados via pressão internacional por parte das Nações Unidas e dos Estados Unidos. $\mathrm{O}$ 
recrudescimento das penas ao crime de tráfico foi acompanhado ao longo da década de 1990 de um discurso cada vez mais duro e repressivo com relação à figura do traficante no Brasil, qualificando-o como um inimigo interno.

Como resultado dessas transformações, em toda a América Latina os Estados Unidos estimularam o emprego de forças militares no combate à criminalidade, sobretudo aquela associada ao tráfico de drogas, processo este denominado pela literatura como "militarização" (PEREIRA, VILLELA, 2019). Apesar de certa resistência ao projeto norte-americano de militarizar o combate às drogas, as Forças Armadas brasileiras passaram a ser empregadas progressivamente em ações de repressão em áreas urbanas, sobretudo nos morros do Rio de Janeiro, e nas fronteiras amazônicas, na forma de apoio logístico, inteligência, incursões e apreensão, em parte pelo convencimento de que a guerra às drogas norteamericana nos países andinos resultaria na transposição do problema do tráfico aos países vizinhos, como o Brasil. Se a presença das Forças Armadas nas ruas da cidade já não era uma novidade no Brasil, os anos 1990 inauguraram seu engajamento em torno da temática das drogas.

No início do governo Fernando Henrique Cardoso foram realizadas as Operações Rio I (1994) e II (1995) com o fim de reconquistar áreas de favela no Rio de Janeiro dominadas pelo tráfico de drogas. Estas operações são exemplos marcantes do novo papel que passou a ser atribuído às Forças Armadas na segurança interna do país, chamadas pela ameaça representada pelo tráfico de drogas. Na ocasião, o General Câmara Senna, militar responsável pela operação nas favelas do Rio, em entrevista à "Folha de S. Paulo", assumiu que as Forças Armadas são treinadas para a guerra e que, portanto, "infelizmente alguns direitos constitucionais estão sendo prejudicados (...) nós não somos um batalhão de assistentes sociais. É impossível evitar um ou outro excesso" (RODRIGUES, 23 de novembro de 1994, p. 5). Ou seja, em nome do combate a uma ameaça de dimensões nacionais, justificam-se ações que colocam em risco os direitos constitucionais básicos.

Essa prática se manteve recorrente nos governos seguintes. $O$ estabelecimento de UPPs (Unidades de Polícia Pacificadora) nas favelas do Rio de Janeiro em 2008, as ocupações dos Complexos da Pena e do Alemão em 2010 e 
dos Complexos de Manguinhos, Maré, Cidade de Deus, Muquiço, Chapadão e Pedreira durante as Olimpíadas de 2016 são exemplos dessas transformações. Ações que visavam à "ocupação" e "retomada do território" assemelharam-se muito a um cenário de guerra ou com operações de paz. Não por acaso, foram recrutados para tais operações fuzileiros navais com experiência nas missões da ONU no Haiti, a MINUSTAH.

Veículos blindados, helicópteros e armas pesadas compuseram aquele cenário (SOUZA, 2015, p. 208). Ademais, as militarizações também se manifestam de formas menos espetaculares, como revela a crescente tendência de que militares assumam a gestão da segurança pública no país, como em secretaria de estados e municípios (SOUZA, 2015, p. 208). Por sua vez, a força de elite da Polícia Militar do Rio de Janeiro, o Batalhão de Operações Especiais (BOPE) e a Coordenadoria de Recursos Especiais (CORE) da Polícia Civil do Rio de Janeiro informalmente enviaram policiais à MINUSTAH para oferecer treinamento e também observar o uso de novas tecnologias que lá estão sendo empregadas (TOLEDO, 11 de janeiro de 2011).

Com o objetivo de formalizar essa prática, em 1999 foi aprovada a Lei Complementar $n^{\circ} 97$ de 1999, que dispôs sobre as normas gerais para o emprego das Forças Armadas na garantia da lei e da ordem "após esgotados os instrumentos destinados à preservação da ordem pública e da incolumidade das pessoas e do patrimônio, relacionados no art. 144 da Constituição Federal", justificando o emprego das Forças Armadas na segurança pública em situações consideradas extremas, em que todos os recursos legítimos estivessem esgotados. Posteriormente, em 2010, instaurou-se a Lei Complementar $n^{\circ} 136$, concedendo às Forças Armadas o poder de polícia para atuar em ações preventivas e repressivas nas fronteiras do país contra delitos transfronteiriços.

Como mais uma iniciativa que visava a militarizar o combate ao tráfico de drogas, em 1998 foi proposta uma alteração do código aeronáutico que permitiria a destruição de aeronaves civis suspeitas de participar do tráfico ilícito de entorpecentes, a chamada Lei do Abate (Lei $n^{\circ}$ 9.614/98) (FEITOSA; PINHEIRO, 2012, p. 66). A lei atribuía ao Presidente da República a competência de dar a 
ordem final para a destruição de aeronaves consideradas hostis após "esgotados os meios coercitivos legalmente previstos".

A aprovação da Lei do Abate foi objeto de grandes controvérsias entre os Estados Unidos e o Brasil e teve sua regulamentação congelada por seis anos (Decreto 5.144/04), por conta de um pedido da então secretária de Estado dos Estados Unidos, Madeleine Albright. Segundo papéis do Itamaraty obtidos pelo jornal "Folha de S. Paulo", para que a lei fosse aprovada, os Estados Unidos exigiram que o governo brasileiro declarasse que a soberania do Brasil estava ameaçada pelo tráfico de drogas, proposta que foi rechaçada pelo Brasil, principalmente pelo setor militar, pois representaria um aval para a ação norteamericana em território nacional (VALENTE; ODILLA, 4 de setembro de 2011). Se o Brasil regulamentasse a lei sem acatar as exigências norte-americanas, os Estados Unidos cortariam toda informação de inteligência sobre tráfego aéreo na Amazônia. Por meio de uma carta à Madeleine Albright, o ministro das relações exteriores, Luiz Felipe Lampreia, declarou que decidiu "congelar" a aplicação da lei (VALENTE; ODILLA, 4 de setembro de 2011). Esse episódio revela a importância que os Estados Unidos davam ao reconhecimento, por parte do Brasil, de que as drogas se tratavam de uma ameaça à segurança nacional do país. Por outro lado, também indica que havia resistência e desconfiança por parte de algumas autoridades brasileiras com relação às consequências que esse reconhecimento público poderia trazer ao Brasil, frente à possibilidade de ingerência ou intervenções por parte dos Estados Unidos.

O caso demonstra que esse processo não aconteceu sem resistências, contudo. A agenda de segurança internacional posta pelos Estados Unidos após os anos 1990 levantou questões sobre a redefinição do conceito de soberania e os critérios de intervenção, o que gerou sérias preocupações dos militares brasileiros com relação à presença militar norte-americana no combate às drogas, compreendidas como uma possível ameaça à Amazônia brasileira (CERVO; BUENO, 2011, p. 503; HERZ, 2006, p. 207). De modo geral, havia uma divergência entre a Polícia Federal, que cooperava com agências de policiamento norteamericanas e delas recebia recursos para o combate ao tráfico de drogas, e as Forças Armadas, que são tradicionalmente contra a presença de forças 
estrangeiras em território nacional e dos exercícios realizados na Amazônia (BANDEIRA, 2010, p. 109).

Ainda assim, a ampliação e internacionalização do conceito de segurança foi sendo incorporada pela elite política no Brasil ao longo da década de 1990 e trouxe o tema do tráfico de drogas ao centro deste debate (HERZ, 2006). As novas políticas de drogas, as interpretações que as autoridades brasileiras tinham sobre elas, os discursos e pronunciamentos trazidos neste presente trabalho visam demonstrar que o Brasil passou a incorporar o tema das drogas à sua agenda de segurança internacional.

A construção da segurança é uma forma de representação de um objeto em particular, neste caso, o tráfico de drogas. Para entender como um fenômeno passou a ser encarado como uma ameaça à segurança é preciso enquadrá-la sob o contexto social, político e histórico que permitiram que este processo se consolidasse naquele dado período e ambiente (BUZAN et al, 1998) Um fenômeno é definido como uma ameaça à segurança através da linguagem, imagens, ações, práticas burocráticas, por vezes rotineiras, como o caso brasileiro demonstra (MCDONALD, 2008, p. 569).

Para Huysmans (1998, p. 4), a forma como um fenômeno é narrado cria certas expectativas na sociedade e molda práticas específicas que serão empregadas para combatê-lo. No discurso da segurança, o fenômeno é dramatizado e apresentado como um problema de suprema prioridade, o que acarreta no direito de trata-lo politicamente como prioridade e por meios excepcionais (BUZAN et al, 1998). As reformas institucionais que se desenvolveram ao longo da década de 1990 são resultado de uma narrativa específica que ganhou força no Brasil ao longo deste período, em decorrência da importância que o país ganhou na cadeia internacional do tráfico da cocaína desde meados da década de 1980, assim como da incorporação das noções e concepções construídas internacionalmente em torno do problema das drogas.

\section{CONCLUSÃO}


A década de 1990 foi um período marcante para que o problema das drogas passasse ganhasse destaque na agenda internacional do Brasil e passasse a ser qualificado como uma ameaça à segurança internacional. Ainda que não se tratasse de uma preocupação nova, é marcante a importância que dimensão internacional do tráfico de drogas assumiu nos discursos de autoridades políticas e no desenho das políticas de drogas nesse período. A preocupação em prestar contas internacionalmente $\mathrm{e}$, por outro lado, incorporar as pressões e recomendações da ONU e dos Estados Unidos expressa essa mudança.

No âmbito da ONU, também assistimos a uma transformação nesse período. É possível notar um movimento de securitização do problema das drogas. Se na Convenção de 1961 é enfatizada os danos causados pelo consumo das drogas, na Convenção de 1988, a relação entre as drogas e o crime transnacional foi trazida para o centro de suas preocupações, entendendo o problema das drogas não apenas uma ameaça ao indivíduo, mas uma ameaça aos Estados nacional e à segurança internacional. A partir de então, todos os documentos da ONU tratariam do tema das drogas atrelado à questão da criminalidade transnacional.

A ONU teve um papel extremamente importante neste processo. Os relatórios anuais da INCB e as representações da INCB e da UNODC no Brasil exerceram uma considerável pressão sobre as autoridades do país para que os termos acordados nas convenções internacionais fossem implementadas na legislação brasileira. Os Estados Unidos, por meio do processo de certificação e da publicação dos International Narcotics Control Strategy Report (INCSR) anuais, de pressões diplomáticas diretas, dos acordos bilaterais, do financiamento e treinamento de agentes brasileiros especializados no combate às drogas, e da ação direta das agências norte-americanas de inteligência e combate às drogas em território brasileiro, certamente tiveram grande influência sobre as políticas de combate às drogas implementadas no Brasil ao longo da década de 1990. Além disso, na condição de principal promotor do regime de proibição da ONU, os Estados Unidos também influenciaram indiretamente as políticas de combate às drogas no Brasil por meio destas organizações.

As dimensões internacionais das políticas de drogas tem sido cada vez mais destacado objeto de produção acadêmica nas Relações Internacionais. Se um 
conjunto cada vez mais vasto de autores identificam influências internacionais sobre o processo de desenvolvimento da política de drogas brasileira ao longo todo o século passado, é crucial que as pesquisas sigam avançando nos diferentes mecanismos e interações que permitem a transferência dessas políticas internacionalmente.

Ainda que esses mecanismos e interações sejam distintos e, por vezes, pouco claros, é possível identificar que o Brasil também passou a qualificar o problema das drogas dentro de um vocabulário da segurança construído internacionalmente. Com essa pesquisa, portanto, identificamos que, a partir de então, o tráfico de drogas passou a ser definido politicamente como uma ameaça à segurança nacional do país. Isso significou dramatizar seu tratamento e apresentar o problema como de suprema prioridade, dando assim ao Estado o direito de trata-lo politicamente por meios excepcionais (BUZAN et al, 1998). Ou seja, houve importante influência internacional sobre as políticas de combate às drogas no Brasil, na medida em que o país passou a incorporar as definições de segurança internacionais que vinham se consolidando internacionalmente devido ao crescimento do tráfico de drogas no país, à presença norte-americana no combate às drogas na América Latina, às pressões dos organismos internacionais para que o país implementassem os termos acordados em seus compromissos e à mudança no modelo inserção internacional do país na década de 1990.

\section{REFERÊNCIAS BIBLIOGRÁFICAS}

ADORNO, Sérgio; SALLA, Fernando. Criminalidade organizada nas prisões e os ataques do PCC. Estudos Avançados, 21 (61), 2007. P. 7-29.

AGÊNCIA ESTADO. Um Novo Acordo sobre as Drogas. O Estado de S. Paulo, Brasília, p. 14, 9 de abril de 1986.

ANDREAS, P.; NADELMANN, E. Policing the Globe: criminalization and crime control in international relations. Oxford: Oxford University Press, 2006.

ANDREAS, P.; PRICE, R. From War Fighting to Crime Fighting: Transforming the American National Security State. International Studies Review, 3, n. 3, p. 31-52, 2001.

BAGLEY, B. M. US Foreign Policy and the War on Drugs: Analysis of a Policy Failure. Journal of Interamerican Studies and World Affairs, 30, n. 2/3, p. 189-212, 1988. 
BAGLEY, B. M.; SALMERÓN CASTRO, F. I. Mitos de la militarización : Ios militares estadunidenses y la guerra contra las drogas.Foro Internacional.1991, p. 30.

BANDEIRA, L. A. M. As relações perigosas: Brasil - Estados Unidos (de Collor a Lula, 1990-2004). Rio de Janeiro: Civilização Brasileira, 2010.

BEWLEY-TAYLOR, D.; JELSMA, M. Fifty Years of the 1961 Single Convention on Narcotic Drugs: A Reinterpretation. Transnational Institute. 2011.

BIGO, D. When Two Become One: Internal and External Securitization in Europe. In: KELSTRUP, M., WILLIAMS, MICHAEL C. (Ed.). International Relation Theory and the politics of European Integration, Power, Security and Community. London: Routledge, 2000. p. 171-205.

BOITEUX, L. Controle penal sobre as drogas ilícitas: o impacto do proibicionismo no sistema penal e na sociedade. 2006. (Doutorado) -, Faculdade de Direito da Universidade de São Paulo, São Paulo.

BRAGA, I.; MONTEIRO, T. FHC critica a má articulação no combate ao narcotráfico. Estado de S. Paulo, São Paulo, p. 20, 1 de abril de 1999.

BRANDÃO, Guilherme S. A criminalização Das Drogas No Brasil: Uma Genealogia Do Proibicionismo. Revista De Direito, Vol. 9, nº 02, março de 2018, p. 87-117.

BUZAN, B.; HANSEN, L. A Evoluçao Dos Estudos De Segurança Internacional. UNESP, 2012.

BUZAN, B.; W/EVER, O.; DE WILDE, J. Security: A New Framework for Analysis. Lynne Rienner Pub., 1998.

CAMPOS, M. S.; ALVAREZ, M. C. Pela metade Implicações do dispositivo médicocriminal da "Nova" Lei de Drogas na cidade de São Paulo. Tempo Social, revista de sociologia da USP, v. 29, n. 2, 2019.

1998.

CAMPOS, M. S. Entre doentes e bandidos: A tramitação da lei de drogas ( ${ }^{\circ}$ 11.343/2006) no Congresso Nacional. Revista de Estudos Empíricos em Direito, v. 2, p. 156-173, 2015.

CARDOSO, F. H. Discurso na Sessão Especial sobre Drogas, da Assembleia Geral das Nações Unidas (Nova York, 8 de Junho de 1998). Brasília: Biblioteca da Presidência da República 1998.

CARVALHO, S. A Política Criminal de Drogas No Brasil - Estudo Criminológico e Dogmático. São Paulo: Editora Saraiva, 2013. 
CARVALHO, J.C. Regulamentação e criminalização das drogas no Brasil: A Comissão Nacional de Fiscalização de Entorpecentes. Rio de Janeiro: Multifoco, 2013.

CERVO, A. L. Inserção Internacional: formação dos conceitos brasileiros. . São Paulo: Editora Saraiva, 2008.

CERVO, A. L.; BUENO, C. História da política exterior do Brasil. São Paulo: Ed. Ática, 2011.

CORRÊA, L. F. D. S. O Brasil nas Nações Unidas: 1946-2006. Fundação Alexandre de Gusmão, 2007.

CÂMARA DOS DEPUTADOS. CPI do Narcotráfico. BRASIL, G. F. D. Brasília 1991.

DAMMERT, L. Militarization of Public Security in Latin America:Where Are the Police? In: SANTOS, M. G. e RANDALL, S. J. C. (Ed.). Papers in Military and Strategic Studies: Latin American Security.Calgary: Centre for Military and Strategic Studies., 2013.

DEL OLMO, R. A Face Oculta das Drogas. Rio de Janeiro: Editora Revan, 1990. DEPARTMENT OF STATE. International Narcotic Control Strategy Report (INCSR) 1996 South America. Washington: Bureau of International Narcotics and Law Enforcement Affairs (INL) 1996.

DEPARTMENT OF STATE. International Narcotic Control Strategy Report (INCSR) 1997 South America.. Washington: Bureau of International Narcotics and Law Enforcement Affairs (INL) 1997.

DEPARTMENT OF STATE. International Narcotic Control Strategy Report (INCSR) 1998. Washington: Bureau of International Narcotics and Law Enforcement Affairs (INL) 1998.

DEPARTMENT OF STATE. International Narcotic Control Strategy Report (INCSR) 1999. Washington: Bureau of International Narcotics and Law Enforcement Affairs (INL) 2000.

DEPARTMENT OF STATE. International Narcotic Control Strategy Report (INCSR) 2020. Washington: Bureau of International Narcotics and Law Enforcement Affairs (INL) 2020.

EDWARDS, A.; GILL, P. After transnational organised crime? The politics of public safety In: EDWARDS, A. e GILL, P. (Ed.). Transnational Organised Crime: Perspectives on global security New York: Routledge, 2003. p. 264-281.

EVELIN, G.; FARIA, T. Wálter Maierovitch: um juiz em guerra Revistalstoé, 23 de junho de 1999. 
FAFT. Annual Report 1999-2000:Financial Action Task Force on Money Laundering. OCDE. Paris 2000.

FEITOSA, G. R. P.; PINHEIRO, J. A. D. O. Lei do Abate, guerra às drogas e defesa nacional. Revista Brasileira de Política Internacional, 55, p. 66-92, 2012.

FOLHA DE S. PAULO. País quer prender 10 maiorestraficantes. Jornal Folha de São Paulo. p. 19 de abril de 1996.

HERZ, M. Brazil, Andean Region and U.S Regional Security Policy. In: LOVEMAN, BRIAN (Ed.). Addicted to Failure: U.S Security Policy in Latin America and the Andean Region. Lanhan: Rowman \& Littlefield Publishers Inc., 2006. p. 197- 223.

HUYSMANS, J. International Politics of Insecurity: Normativity, Inwardness and the Exception. European Journal of International Relations, 4, n. 4, p. 479-505, 1998.

JOBIM, N. Uma tarefa que começa em casa. Folha de S. Paulo, 22 de novembro de 1996. Disponível em: http: //www1.folha.uol.com.br/fsp/1996/11/22/opiniao/9.html.

KRASNER, S. D. Structural Causes and Regime Consequences: Regimes as Intervening Variables. International Organization, 36, n. 2, p. 185-205, 1982.

LABATE, B. C.; RODRIGUES, T. Politicas de Drogas no Brasil: Conflitos e Alternativas. Campinas: Mercado de Letras, 2018.

LAFER, C.; FONSECA JR, G. Questões para a diplomacia no contexto internacional das polaridades indefinidas. In: FONSECA JR, G. e CASTRO, S. H. N. (Ed.). Temas de Política Externa Brasileira II. São Paulo: Terra \& Paz, 1997. p. 49-78.

LIMA, M. R. S.; HIRST, M. O Brasil e os Estados Unidos: Dilemas e Desafios de uma Relação Complexa. In: FONSECA JR., G. e CASTRO, S. H. N. (Ed.). Temas de Política Externa Brasileira II. São Paulo: Paz \& Terra, 1994.

MACHADO, L. O. Medidas institucionais para o controle do tráfico de drogas e da lavagem de dinheiro e seus efeitos geoestratégicos na região Amazônica brasileira. Cadernos IPPUR, XXI, n. 1, p. 7-32, 2007.

MARTINS FILHO, J. R. As Forças Armadas brasileiras e o Plano Colômbia. In: CASTRO, C. (Ed.). Amazônia e Defesa Nacional. Rio de Janeiro: Editora GV, 2006. p. 13-30.

MCDONALD, M. Securitization and the Construction of Security. Journal of International Relations, 14, n. 4, p. 463-587, 2008.

MIYAMOTO, S. A Política de Defesa Brasileira e a Segurança Regional. Contexto Internacional, 22, n. 2, p. 431-473, 2000. 
MRE. Resenha de Política Exterior do Brasil. Brasília: Ministério das Relações Exteriores 1996.

MRE. Resenha de Política Exterior do Brasil (2 Semestre de 2001). Ministério das Relações Exteriores 2001.

O ESTADO DE S. PAULO. Brasil rota importante para tráfico de droga. Edição de 22 de Outubro de 1982. P. 25.

O ESTADO DE S. PAULO. ONU adverte: o Brasil ameaçado pelos tóxicos. Edição de 13 de Janeiro de 1987. P. 11.

O ESTADO DE S. PAULO. O Problema dos Tóxicos. Edição de 30 de Janeiro de 1985. P. 12.

ONU. Report of the International Narcotics Control Board for 1983. (INCB), I. N. C. B. Nova York: United Nations 1983.

ONU. United Nations Convention against Illicit Traffic in Narcotic Drugs and Psychotropic Substances. UNODC. New York 1988.

ONU. Report of the International Narcotics Control Board for 1990. New York: International Narcotics Control Board (INCB) 1990.

ONU. Report of the International Narcotics Control Board for 1992. New York: International Narcotics Control Board (INCB) 1992.

ONU. Report of the International Narcotics Control Board for 1994. New York: International Narcotics Control Board (INCB) 1994.

ONU. Report of the International Narcotics Control Board for 1995. New York: International Narcotics Control Board (INCB) 1995.

ONU. Report of the International Narcotics Control Board for 1997. New York: International Narcotics Control Board (INCB) 1997.

ONU. XX United Nations General Assembly Special Session (UNGASS) Devoted to Countering the World Drug Problem Together. Political Declaration Guiding Principles of Drug Demand Reduction and Measures to Enhance International Cooperation to Counter the World Drug Problem.New York and Vienna: United Nations Publications 1998.

PEREIRA, P. Securitização do Crime Organizado Transnacional nos Estados Unidos na década de 1990. 2011. (Tese (doutorado)) - Ciências Políticas, UNICAMP, Campinas, SP.

PEREIRA, P. Os Estados Unidos e a ameaça do crime organizado transnacional nos anos 1990. Revista Brasileira de Política Internacional, 58, n. 1, p. 84-107, 2015. 
PRESIDÊNCIA. Política Nacional Antidrogas (PNAD). Brasília: Presidência da República 2002.

RODRIGUES, F. Direitos são 'prejudicados' afirma General a Vereadores. Para Senna tropas do exército não são "batalhão de assistência social". Folha de S. Paulo, São Paulo, p. 5, 23 de novembro de 1994.

RODRIGUES, P. L. Maciel diz que narcotráfico já se tornou epidemia. Estado de $S$. Paulo. P. 5, 9 de junho de 1998.

RODRIGUES, T. Narcotráfico e militarização nas Américas: vício de guerra. Contexto Internacional, 34, p. 9-41, 2012.

RODRIGUES, T.; LABATE, B. C. Brazilian Drug Policy: Tension Between Repression and Alternatives. In: CAVNAR, C.:LABATE, B. C., et al (Ed.). Drug Policies and the Politics of Drugs in the Americas. Switzerland: Springer International Publishing, 2016. p. $187-208$.

SAAD, Luísa G. Fumo de negro: a criminalização da maconha no Brasil (1890-1932). Dissertação (Mestrado) - Faculdade de Filosofia e Ciências Humanas, Universidade Federal da Bahia (UFBA). Salvador, 2013.

SILVA, Luiza Lopes. A questão das drogas nas relações internacionais: uma perspectiva brasileira. Brtasília: Fundação Alexandre de Gusmão, 2013.

SHELLEY, L. Transnational organized crime: an imminent threat to the nation- state? 48, n. 2, p. 463-489, 1995.

SILVA, L. L. A Questão das Drogas nas Relações Internacionais: uma perspectiva brasileira. Brasília: Fundação Alexandre de Gusmão, 2013.

SOUZA, L. A. F. D. Dispositivo militarizado da segurança pública. Tendências recentes e problemas no Brasil. Sociedade e Estado, 30, p. 207-223, 2015.

THE WHITE HOUSE. National Security Decision Directive (NSDD-221).The White House. Washignton 1986.

TOKATLIAN, J. G. The War on Drugs and the Role of SOUTHCOM. In: BAGLEY, B. M. e ROSEN, J. D. (Ed.). Drug Trafficking, Organized Crime, and Violence in the Americas Today.Florida: University Press of Florida, 2015. p. 67-86.

TORCATO, Carlos Eduardo Martins. A história das drogas e sua proibição no Brasil. Tese, Universidade de São Paulo / Programa de Pós-Graduação em História Social, São Paulo, 2016. 
TOLEDO, M. Bope fará "viagem de instrução" ao Haiti. Jornal Folha de S. Paulo, 11 de janeiro de $2011 . \quad$ Disponível em: < https://www1.folha.uol.com.br/fsp/mundo/ft1101200812.htm>.

VALENTE, R.; ODILLA, F. Brasil sofreu pressão dos EUA contra "Lei do Abate". Folha de S. Paulo, 4 de setembro de 2011. Disponível em: https://www1.folha.uol.com.br/fsp/mundo/ft0409201105.htm.

VILLA, R. EUA-América do Sul: dinâmicas do complexo de segurança regional. In: CEPIK, M. (Ed.). Segurança internacional: práticas, tendências e conceitos. São Paulo: Hucitec, 2010. p. 23-59.

VILLELA, P. A "guerra às drogas" e a transnacionalização do policiamento estadunidense no Brasil: as relações entre a Polícia Federal e a DEA entre os anos 1990 e 2000. São Paulo: Programa de Pós-graduação em Relações Internacionais San Tiago Dantas (UNESP, UNICAMP, PUC-SP) - Tese (Doutorado em Relações Internacionais), 2020.

WALKER III, W. O. The Limits of Coercive Diplomacy: U.S. Drug Policy and Colombian State Stability, 1978-1997. In: FRIMAN, H. R. e ANDREAS, P. (Ed.). The Illicit Global Economy and State Power. Oxford: Rowman \& Littlefield Publishers, 1999. cap. 6, p. 143-171.

WALT, S. M. The Renaissance of Security Studies. International Studies Quarterly, 35, n. 2, p. 211-239, 1991.

WILLIAMS, P. Transnational criminal organisations and international security. Survival, 36, n. 1, p. 96-113, 1994/03/01 1994.

Recebido em: 17/01/2020

Aprovado em: 06/10/2020 